IJIET, e-ISSN 2548-8430, p-ISSN 2548-8422, Vol. 2, No. 1, January 2018

International Journal of Indonesian Education and Teaching http://e-journal.usd.ac.id/index.php/IJIET

Sanata Dharma University, Yogyakarta, Indonesia

\title{
DEVELOPMENT OF CHARACTER ASSESSMENT INSTRUMENTS IN SERVICE-LEARNING AT BIOLOGY EDUCATION DEPARTMENT SANATA DHARMA UNIVERSITY
}

\section{Luisa Diana Handoyo \& Ika Yuli Listyarini}

Biology Education Department

Faculty of Teacher Training and Education, Sanata Dharma University

luisadianahandoyo@usd.ac.id \& ika_yuli86@yahoo.com

https://doi.org/10.24071/ijiet.v2i1.960

received 24 August 2017; revised 7 November 2017; accepted 15 December 2017

\begin{abstract}
Service-learning is one of the learning methods that combine learning in the classroom with service activities to the community. In service-learning, students are invited to apply the lecture material in solving the problems in the community directly. In the process, many student characters will be trained and developed. This research focuses on developing character assessment instruments that develop after the implementation of service-learning activities in Biology Education Program, Sanata Dharma University, Yogyakarta. The purpose of this research is to develop a character assessment instrument in the form of questionnaires for students, especially in Biology Education at Sanata Dharma University. Questionnaires developed through the stages of the development of the instrument, including determining the purpose of the preparation of the instrument, find the relevant theory, compile instrument indicators, compile instrument, content validation, and revisions based on input validator. Instrument validation is done through content validation with expert judgment. Based on the result of content validation by expert judgment, Aiken index is obtained at 0.85 with high validation category. Based on these results, the character assessment questionnaire developed can be implemented in the learning to assess the character development of students after implementing service-learning.
\end{abstract}

Keywords: service-learning, assessment instrument, character

\section{Introduction}

Currently, the Indonesian government is paying particular attention to the development of character that is integrated through education from early childhood to university levels. The development of the character of this student felt as a very important and urgent thing to do given the declining morale and character of the younger generation. The decline in the character of this young generation can be seen in many ways. In terms of association, there is a tendency of increasingly rampant juvenile delinquency, such as acts of extortion, bullyingin schools, a brawl between students, drug trafficking, free sex to lead to abortion, 
and so forth. The proliferation of bribery and corruption in various fields, let alone carried out by the stakeholders who belong to the literate, also indicates the need for the application of character education in schools and communities. The world of education is also inseparable from many cases that show the decline of characters, such as cheating, search for key answers before the National Exam, the development of instant culture, and even plagiarism that occurs in the academic circles (Samani \& Hariyanto, 2013).

Sanata Dharma University (SDU) as a Jesuit University in Indonesia is also very concerned about developing the character of the young generation. This is as stated in his vision "Being a superior digger of truth and humanist for the realization of an increasingly dignified society". With its "smart and humanist" motive, USD has 3 major missions, one of which is "Developing a holistic education system that is a blend of academic excellence and human values through a personalist, dialogical, pluralistic, and transformative approach." Development of students, SDU prioritizes the 3C development, namely Competence, Conscience, and Compassion. In a sense, SDU graduates are expected to not only have good competence but also have a high conscience and compassion. In line with the vision and mission of the SDU above, Biology Education Department is expecting its graduates to be a generation that has a good character as stated in its vision, which is "Being a study program that produces a tough Biologist of the nation's intellectual always be humanist by prioritizing the dialogical approach in education and management nature sustainably ". From the vision, it is clear that the Biology Education Department always strives to develop the character of the student, either through the learning process or from various activities conducted by students outside the lecture activities.

In the learning process, Biology Education Department strives to develop the character of students through the application of various learning methods such as cooperative learning, problem-based learning, project-based learning, inquiry, service-learning, and several other innovative methods. One of the methods developed is service-learning. Service-learning is a learning method that combines learning theory with service activities to the community (Warren, 2012). Learning with service-learning methods allows students to learn directly from the communities they serve. Learning derived from the students comes from the context of society related to the problems they face. In this case, students engagein activities devoted to human and community needs (Jacoby, 2015). Thus, students can learn to apply the theories that have been obtained in class to the community directly.

Service-learning in Biology Education Department has been developed since 2010 in Nutrition and Health Sciences courses. In its implementation, servicelearning has undergone many developments, ranging from student involvement in Pos Pelayanan Terpadu (Posyandu) activities until now has developed with the involvement of students in providing counseling to the community related to nutrition and health issues. From these activities, students get many benefits such as improving their understanding of lecture materials to the development of student character (Handoyo, 2014). Characters that arise during service-learning activities include creative character, responsibility, hard 
work, communicative and social care. In another study, it was stated that servicelearning has other benefits such as improving student achievement (Warren, 2012), contributing to student's affective learning, such as self-confidence, social responsibility, and self-esteem, developing tolerant behavior toward cultural differences (Kezar \& Rhoads, 2001). Service-learning is seen as an educational approach that allows students to think, value, care, or does something and prepares to face future challenges (Karmansyah, Muljadi, \& Saputro, 2013).

Based on Mark F. Toncar's research, et.al. (2006) has developed a scale to know the benefits of service-learning. The scale for measuring student's perceptions of the service-learning experience is called the SELEB scale (Servicelearning Benefit). The scale consists of 20 variables that are grouped into 4 factors, namely (1) practical ability, (2) interpersonal skills, (3) citizenship, and

(4) personal responsibility. Factors 1 and 2 are skills-related benefits, while the 3rd and 4th factors show the benefits of a personal nature.

The problem faced in the assessment of character in learning at Biology Education Department of SDU is the unavailability of the instrument to assess the development of student character after implementing service-learning. This assessment instrument is very necessary to be developed to facilitate the teacher in measuring the benefits of the implementation of service-learning for the development of student character. After the teacher knows that service-learning can develop student's character, it is expected that the lecturer can continue to develop the service-learning in their teaching experience. This study aims todevelop a character assessment instrument in Service-learning at Biology Education Department.

\section{Method}

Character assessment instrument in service-learning, developed by stages in accordance with the stages of instrument development by Retnawati (2016), which determines the purpose of the preparation of the instrument, find relevant theories, prepare instrument grain indicators, arrange instrument items, content validation, and revisions based on validator's input.

\section{Findings and Discussion}

Character assessment instrument in service-learning developed in this research through the stages of preparation of instruments as described below.

\section{Arrange Instrument Grain Indicators}

The character development instrument in this study measures 8 characters that can develop during the implementation of service-learning. These eight characters can develop as long as the students follow each stage of service- learning, namely investigation, planning and preparation, action, reflection, and demonstration. The characters that appear can be seen in table 1 below. 
Table 1. Character Value Emerging during Service-learning

\begin{tabular}{|c|c|c|}
\hline No. & Stage & Character Value \\
\hline 1 & Investigation & $\begin{array}{l}\text { Curiosity, communicative, social care, } \\
\text { honest }\end{array}$ \\
\hline 2 & Planning and Prepare & $\begin{array}{l}\text { Creative, hard work, communicative, } \\
\text { responsibility }\end{array}$ \\
\hline 3 & Action & $\begin{array}{l}\text { Hard work, discipline, responsibility, } \\
\text { communicative, social care }\end{array}$ \\
\hline 4 & Reflection & Honest \\
\hline 5 & Demonstration & Honest, communicative \\
\hline
\end{tabular}

Next step was to determine the indicators. Indicators are determined based on relevant theoretical studies. Indicators in this research include 8 aspects of the character that is curiosity, hard work, responsibility, discipline, social care, communicative, creative and honest. Indicators of each character aspect can be seen in table 2 .

Table 2. Character Components and Indicators in Service-learning

\begin{tabular}{|c|c|c|}
\hline No. & Character Value & Indicators \\
\hline 1 & Curiosity & $\begin{array}{l}\text { - Seek information from various sources } \\
\text { - Have the initiative }\end{array}$ \\
\hline 2 & Hard Work & - Not easy to despair in doing the task \\
\hline 3 & Responsibility & - complete the task well \\
\hline 4 & Discipline & $\begin{array}{l}\text { - Collect reports/tasks result in time } \\
\text { - Conducting activities in accordance with the schedule }\end{array}$ \\
\hline 5 & Social Care & $\begin{array}{l}\text { - Have a sense of empathy towards community problems } \\
\text { - Able to provide solutions to the problems that exist in } \\
\text { the community }\end{array}$ \\
\hline 6 & Creative & $\begin{array}{l}\text { Able to provide innovative ideas in overcoming the } \\
\text { problems that exist in the community }\end{array}$ \\
\hline 7 & Communicative & $\begin{array}{l}\text { - Speak politely } \\
\text { - Be able to communicate ideas to friends and } \\
\text { communities }\end{array}$ \\
\hline 8 & Honest & $\begin{array}{l}\text { - Prepare activity reports in accordance with reality } \\
\text { - Report data according to community conditions }\end{array}$ \\
\hline
\end{tabular}

\section{Organizing Instruments Items}

Instrument preparation is done by looking at indicators that have been arranged in the grid. Instrument items can be seen in table 3 below. Items are arranged in the form of a Lickert-scale questionnaire with a choice of "Strongly Agree (SA)", "Agree (A)", "Disagree (DA)" and "Strongly Disagree (SD)" responses. The 13 indicators are then translated into 21 statements divided into 14 positive statements and 7 negative statements as shown in table 3 below. 
Table 3. Character Assessment Items in Service-learning

\begin{tabular}{|c|c|c|c|c|c|}
\hline \multirow[t]{2}{*}{ No } & \multirow[t]{2}{*}{ Statements } & \multicolumn{4}{|c|}{ Response } \\
\hline & & SD & DA & $\mathbf{A}$ & SA \\
\hline 1 & $\begin{array}{l}\text { I am actively seeking information about the problems } \\
\text { in the community from various sources }\end{array}$ & & & & \\
\hline 2 & $\begin{array}{l}\text { The existence of obstacles and difficulties in the } \\
\text { implementation of activities, do not discourage/lower } \\
\text { my spirit in carrying out service-learning activities }\end{array}$ & & & & \\
\hline 3 & $\begin{array}{l}\text { Despite my many lectures, I still carry out service- } \\
\text { learning activities seriously }\end{array}$ & & & & \\
\hline 4 & $\begin{array}{l}\text { I am actively involved in giving ideas about solutions } \\
\text { to problems that exist in the community }\end{array}$ & & & & \\
\hline 5 & $\begin{array}{l}\text { This service-learning activity stimulates my } \\
\text { imagination to help solve the problems in society }\end{array}$ & & & & \\
\hline 6 & $\begin{array}{l}\text { Due to the enormous tasks, my activity report } \\
\text { becomes delayed }\end{array}$ & & & & \\
\hline 7 & $\begin{array}{l}\text { When I know the problems that exist in the } \\
\text { community, I want to help them with the knowledge } \\
\text { and skills I have }\end{array}$ & & & & \\
\hline 8 & $\begin{array}{l}\text { I am actively involved in solving problems in the } \\
\text { community }\end{array}$ & & & & \\
\hline 9 & $\begin{array}{l}\text { This service-learning challenges my creativity to } \\
\text { design innovative programs according to the } \\
\text { problems encountered in society }\end{array}$ & & & & \\
\hline 10 & I prefer to listen to friends opinions & & & & \\
\hline 11 & I always collect reports/assignments on time & & & & \\
\hline 12 & $\begin{array}{l}\text { I can convey ideas to the people in a language } \\
\text { appropriate to the condition/context of the } \\
\text { community }\end{array}$ & & & & \\
\hline 13 & $\begin{array}{l}\text { I only rely on information from lecturers related to } \\
\text { the problems occurs in the community }\end{array}$ & & & & \\
\hline 14 & $\begin{array}{l}\text { reports that I compile in accordance with conditions } \\
\text { in the field }\end{array}$ & & & & \\
\hline 15 & $\begin{array}{l}\text { I obey the schedule of activities that have been } \\
\text { agreed with the group }\end{array}$ & & & & \\
\hline 16 & I am ashamed to express my opinion & & & & \\
\hline 17 & $\begin{array}{l}\text { In order for my report to get good grades, I include } \\
\text { many activities that I do not do }\end{array}$ & & & & \\
\hline 18 & $\begin{array}{l}\text { I carry out service-learning activities with as } \\
\text { necessary only, since i also have many another task }\end{array}$ & & & & \\
\hline 19 & I try to communicate with people in polite language & & & & \\
\hline 20 & I was careless in preparing service-learning programs & & & & \\
\hline 21 & I do all the activities I report in the activity report & & & & \\
\hline
\end{tabular}

\section{Content Validation}

Content validation is done by expert judgment. The expert sees the appropriateness of the indicator with the purpose of developing the instrument, the conformity of the indicator with the theory, looking at the suitability of the instrument with the indicator of the item, looking at the truth of the concept of the 
item, looking at the truth of the content. In this research validation of content done by asking advice from education experts, namely Prof. Dr. Paul Suparno, SJ., M.S.T. and lecturer in Biology Education Program, Drs A. Tri Priantoro, M.For.Sc. The expert gives an assessment of the relevance of the statement item with the indicator being prepared. Score is set with terms, score $1=$ irrelevant, $2=$ less relevant, $3=$ relevant enough, $4=$ relevant and $5=$ highly relevant. Assessment of experts then calculated the index of expert agreement or validator agreement by using Aiken index, by the formula below.

$V=\frac{\Sigma s}{n(c-1)}$

Information:

$\mathrm{V}=$ index of the rater agreement on the validity of the item

$\mathrm{s}=$ score per rater minus the lowest score in the scoring category $(\mathrm{r}-\mathrm{lo})$

$\mathrm{r}=$ score set by each rater

lo $=$ lowest score in the scoring category

$\mathrm{n}=$ number of rater

$\mathrm{c}=$ number of categories that can be selected rater

Aiken index calculation results are then used to determine the validity of the instrument, with the provisions as shown in table 4 below.

Table 4. Description of Aiken Index Calculation Result

\begin{tabular}{c|l} 
Index Value of Aiken & \multicolumn{1}{|c}{ Description } \\
\hline$<0,4$ & Low Validity \\
$0,4-0,8$ & Mediocare Validity \\
$>0,8$ & High Validity
\end{tabular}

Aiken index calculation results each item statement and its description can be seen in table 5 .

Table 5. Calculation Result of Aiken Index at each Statement Point

\begin{tabular}{c|c|c} 
No. & Index Value of Aiken & Description \\
\hline 1 & 0,875 & High validity \\
2 & 1 & High validity \\
3 & 0,875 & High validity \\
4 & 0,875 & High validity \\
5 & 0,625 & Mediocare validity \\
6 & 0,875 & High validity \\
7 & 1 & High validity \\
8 & 0,875 & High validity \\
9 & 0,75 & Mediocare validity \\
10 & 0,625 & Mediocare validity \\
11 & 1 & High validity \\
12 & 1 & High validity \\
13 & 1 & High validity \\
14 & 0,875 & High validity \\
\hline
\end{tabular}




\begin{tabular}{c|c}
15 & 1 \\
16 & 0,75 \\
17 & 0,875 \\
18 & 1 \\
19 & 0,75 \\
20 & 0,875 \\
21 & 1
\end{tabular}

High validity

Mediocare validity

High validity

High validity

Mediocare validity

High validity

High validity

The validator also provides some suggestions as summarized in Table 6 below.

Table 6. Input from Validator

\begin{tabular}{|c|c|c|c|}
\hline $\begin{array}{l}\text { Statement } \\
\text { Number }\end{array}$ & $\begin{array}{l}\text { Input from 1st } \\
\text { Validator }\end{array}$ & $\begin{array}{c}\text { Input from 2nd } \\
\text { Validator }\end{array}$ & Follow Up Improvements \\
\hline 1 & Good & Less focus & $\begin{array}{l}\text { Adding the word "Natural } \\
\text { Resource Management" } \\
\text { Adding the word "Natural } \\
\text { Resource Management" }\end{array}$ \\
\hline 4 & Good & Less focus & $\begin{array}{l}\text { Adding the word "Natural } \\
\text { Resource Management" }\end{array}$ \\
\hline 5 & Not quite right & Less focus & $\begin{array}{l}\text { Made more technical; Adding } \\
\text { the word "Natural Resource } \\
\text { Management" }\end{array}$ \\
\hline 6 & Good & Less focus & $\begin{array}{l}\text { Adding the word "service- } \\
\text { learning" }\end{array}$ \\
\hline 7 & Good & & $\begin{array}{l}\text { Adding the word "Natural } \\
\text { Resource Management" }\end{array}$ \\
\hline 8 & Good & Less focus & $\begin{array}{l}\text { Adding the word "Natural } \\
\text { Resource Management" }\end{array}$ \\
\hline 9 & Not quite right & & $\begin{array}{l}\text { Made more technical and } \\
\text { scalable; Adding the word } \\
\text { "Natural } \\
\text { Management" }\end{array}$ \\
\hline 10 & Not quite right & Less complete & $\begin{array}{l}\text { Made more technical; Adding } \\
\text { the word "Natural Resource } \\
\text { Management" }\end{array}$ \\
\hline 11 & Good & & $\begin{array}{l}\text { Adding the word "Natural } \\
\text { Resource Management" }\end{array}$ \\
\hline 13 & Good & & $\begin{array}{l}\text { Adding the word "Natural } \\
\text { Resource Management" }\end{array}$ \\
\hline 14 & Good & Less complete & $\begin{array}{l}\text { Adding the word "Natural } \\
\text { Resource Management" }\end{array}$ \\
\hline 17 & $\mathrm{i}$ is changed to $\mathrm{I}$ & Less emphasis & Change $\mathrm{i}$ to I \\
\hline 18 & $\mathrm{i}$ is changed to $\mathrm{I}$ & & Change i to I \\
\hline 19 & Not quite right & & Rearrange the sentence \\
\hline 20 & $\mathrm{i}$ is changed to $\mathrm{I}$ & $\begin{array}{l}\text { The choice of } \\
\text { words "careless" } \\
\text { not appropriate }\end{array}$ & $\begin{array}{l}\text { Change i to I, replace the word } \\
\text { "careless" with the word "as } \\
\text { necessary" } \\
\text { Change i to I }\end{array}$ \\
\hline
\end{tabular}




\section{Revisions Based on Validator Input}

Revisions are made based on the input of the validators, and then the revised results are re-consulted on the validator to obtain valid instruments. Revisions are made by clarifying the context of the problems encountered that are related to the courses that will be used for the implementation of the questionnaire that is in the course of Natural Resource Management and changes some statements as suggested by the expert. The result of the instrument revision can be seen in Table 7 below.

Table 7. Instruments after Revised

\begin{tabular}{|c|c|c|c|c|c|}
\hline \multirow[t]{2}{*}{ No. } & \multirow[t]{2}{*}{ Statements } & \multicolumn{4}{|c|}{ Response } \\
\hline & & SD & DA & A & SA \\
\hline 1 & $\begin{array}{l}\text { I am actively seeking information on Natural Resource } \\
\text { Management issues in the community from various } \\
\text { sources }\end{array}$ & & & & \\
\hline 2 & $\begin{array}{l}\text { The existence of obstacles and difficulties in the } \\
\text { implementation of activities, do not discourage/lower } \\
\text { my spirit in carrying out service-learning activities }\end{array}$ & & & & \\
\hline 3 & $\begin{array}{l}\text { Despite my many lecture assignments, I still carry out } \\
\text { service-learning activities related to Natural Resource } \\
\text { Management seriously }\end{array}$ & & & & \\
\hline 4 & $\begin{array}{l}\text { I am actively involved in providing ideas on solutions to } \\
\text { natural resource management problems in the } \\
\text { community }\end{array}$ & & & & \\
\hline 5 & $\begin{array}{l}\text { I am able to provide creative ideas to solve the problems } \\
\text { of Natural Resource Management in the community }\end{array}$ & & & & \\
\hline 6 & $\begin{array}{l}\text { Due to the enormous task, my service-learning report } \\
\text { becomes delayed }\end{array}$ & & & & \\
\hline 7 & $\begin{array}{l}\text { When I know the issues related to Natural Resource } \\
\text { Management in the community, I want to help them with } \\
\text { the knowledge and skills I have }\end{array}$ & & & & \\
\hline 8 & $\begin{array}{l}\text { I am actively involved in solving Natural Resource } \\
\text { Management problems in the community }\end{array}$ & & & & \\
\hline 9 & $\begin{array}{l}\text { I can design an innovative program in line with existing } \\
\text { natural resource management issues }\end{array}$ & & & & \\
\hline 10 & $\begin{array}{l}\text { In planning the program (solution) to overcome the } \\
\text { problems related to Natural Resource Management, I } \\
\text { prefer silent }\end{array}$ & & & & \\
\hline 11 & $\begin{array}{l}\text { I always collect reports/tasks related to the Natural } \\
\text { Resource Management Course on time }\end{array}$ & & & & \\
\hline 12 & $\begin{array}{l}\text { I can convey ideas/ideas to the people in a language } \\
\text { appropriate to the condition/context of the community }\end{array}$ & & & & \\
\hline 13 & $\begin{array}{l}\text { I only rely on information from lecturers related issues } \\
\text { Natural Resource Management in the target community }\end{array}$ & & & & \\
\hline 14 & $\begin{array}{l}\text { Report on Service-Learning activities related to Natural } \\
\text { Resource Management which I arranged in accordance } \\
\text { with the conditions in the field }\end{array}$ & & & & \\
\hline 15 & $\begin{array}{l}\text { I obey the schedule of activities that have been agreed } \\
\text { with the group }\end{array}$ & & & & \\
\hline 16 & I am ashamed to express my opinion/question when & & & & \\
\hline
\end{tabular}




\begin{tabular}{|c|c|c|c|c|c|}
\hline \multirow[t]{2}{*}{ No. } & \multirow[t]{2}{*}{ Statements } & \multicolumn{4}{|c|}{ Response } \\
\hline & & SD & DA & $\mathbf{A}$ & SA \\
\hline 17 & $\begin{array}{l}\text { observation and face to face with the community } \\
\text { In order for my report to get good grades, I include } \\
\text { many activities that I do not all do }\end{array}$ & & & & \\
\hline 18 & $\begin{array}{l}\text { I carry out service-learning activities with as necessary } \\
\text { only, since my other college assignments are also many }\end{array}$ & & & & \\
\hline 19 & I use polite language when communicating with people & & & & \\
\hline 20 & I develop service-learning programs as necessary & & & & \\
\hline 21 & I did all the activities I reported in the activity report & & & & \\
\hline
\end{tabular}

In addition to revisions according to expert input, Aiken index calculations are also performed for the instrument as a whole. The results show that the instrument of character assessment in service-learning has Aiken index of 0.85 and is included in the category of high validity. Based on these values, then developed instruments can be implemented in the course to assess thedevelopment of student characters after implementing service-learning.

\section{Conclusions}

In this research have been compiled the character assessment instrument in Service-learning in the form of a questionnaire. Expert validation results show the value of Aiken index of 0.85 which means that the questionnaire developed has high validity and can be implemented in the course to see the student's response, that is in the aspect of character development after implementing service-learning.

\section{References}

Handoyo, L. D. (2014). Menumbuhkembangkan karakter mahasiswa melalui service-learning program di mata kuliah ilmu gizi dan kesehatan. Jurnal Kependidikan Widya Dharma, 25(2), 183-200.

Jacoby, B. (2015). Service-learning essentials: Questions, answers, and lesson learned. USA: Jossey-Bass.

Karmansyah, H. S., Muljadi, O., \& Saputro, S. K. (2013). Belajar service-learning melalui program cross border service-learning summer institute di hongkong dan tiongkok: Sebuah sharing pengalaman. Journal of Service- learning, 1(1), 44-51.

Kezar, A., \& Rhoads, R. A. (2001). The dynamic tensions of service-learning in higher education: A philosophical perspective. The Journal of Higher Education, 72(2), 148-171.

Mark F. T. J. S. (2006). Uniform assessment of the benefits of service learning: The development, evaluation, and implementation of the seleb scale. Journal of Marketing Theory and Practice, 14(3), 223-238.

Retnawati, H. (2016). Analisis kuantitatif instrumen penelitian: Panduan peneliti, mahasiswa, dan psikometrian. Yogyakarta: Parama Publishing.

Samani, M., \& Hariyanto. (2013). Konsep dan model pendidikan karakter. Bandung: PT. Remaja Rosdakarya.

Warren, J. L. (2012). Does service-learning increase student learning?: A metaanalysis. Michigan Journal of Community Service-learning, 18(2), 56-61. 